\title{
Endothelin-1 expression in airway epithelial cells
}

\section{To the Editors:}

The paper "Erythromycin and clarithromycin attenuate cytokine-induced endothelin-1 expression in human bronchial epithelial cells" by TAKIZAWA et al. [1], recently published in the Journal, provides interesting perspectives on pharmacological modulation of endothelin (ET)-1 expression in human airways, and in the bronchial epithelium in particular. However, a few points from these data need to be clarified.

Immunoreactive ET-1 measured under basal conditions is clearly detectable in both primary bronchial cells and BEAS-2B cells according to table 2 in this article (units not defined, presumably $\mathrm{pg} \cdot \mathrm{mL}^{-1}$ or $\mathrm{pg} \cdot 48 \mathrm{~h}^{-1}$ ). It has previously been shown that serum-exposed bronchial cells, but not undifferentiated basal cells release ET-1 [2]. Although not explicit in the Materials and methods section, it appears that both primary and BEAS-2B cells analysed by TAKIZAWA et al. [1] were exposed to serum-containing medium, otherwise ET-1 would have been barely detectable. This point may be clinically relevant in bronchial asthma where the epithelial layer, normally exposed to low amount of serum-derived proteins, is repeatedly flooded with massive extravasation from the mucosal blood vessels [3]. This mechanism might, indeed explain the increased ET-1 levels in bronchoalveolar lavage fluid from asthmatic patients, as measured by several authors, better than induction by pharmacological doses of pro-inflammatory cytokines.

We similarly interpret the discordance between the data from TAKIZAWA et al. [1] and our own results using the same cell line [4] concerning the modulation of ET-1 expression by dexamethasone. Presumably, serum exposure and squamous differentiation of BEAS-2B cells induces the responsiveness to corticosteroids of the ET-1 gene. It is interesting to note that conflicting results on corticosteroidinduced expression of neutral endopeptidase, the main ET- 1-degrading enzyme, have also been observed in BEAS2B cells $[5,6]$.

Finally, it would be interesting to know whether experiments with incubation periods shorter or longer than 48 $\mathrm{h}$ give comparable results, since the half-life of the ET-1 peptide in culture supernatants is approximately $24 \mathrm{~h}$.

J.-D. Aubert, Ph. Leuenberger, L. Juillerat-Jeanneret Division de Pneumologie, Dépt de Médecine, et Institut de Pathologie CHUV, Université de Lausanne, Switzerland. Fax: 41213141384.

\section{References}

1. Takizawa H, Desaki M, Ohtoshi T, et al. Erythromycin and clarithromycin attenuate cytokine-induced endothelin-1 expression in human bronchial epithelial cells. Eur Respir J 1998; 12: 57-63.

2. Takimoto M, Oda K, Sasaki Y, Okada T. Endothelin-A receptor-mediated prostanoid secretion via autocrine and deoxyribonucleic acid synthesis via paracrine signalling in human bronchial epithelial cells. Endocrinology 1996; 137: 4542-4550.

3. Persson CGA, Erjefalt JS, Greiff L, et al. Plasma-derived proteins in airway defence, disease and repair of epithelial injury. Eur Respir J 1998; 11: 958-970.

4. Aubert JD, Juillerat-Jeanneret L, Leuenberger Ph. Expression of endothelin-1 by human bronchoepithelial and monocytic cell lines: effects of tumor necrosis factor- $\alpha$ and dexamethasone. Biochem Pharmacol 1997; 53: 547552.

5. Borson DB, Gruenert DC. Glucocorticoids induce neutral endopeptidase in transformed human tracheal epithelial cells. Am J Physiol 1991; 260: L83-L89.

6. Proud D, Subauste MC, Ward PE. Glucocorticoids do not alter peptidase expression on a human bronchial epithelial cell line. Am J Respir Cell Mol Biol 1994; 11: 57-65.

\section{REPLY}

\section{From the authors:}

We think that the points raised by J.-D. Aubert and colleagues about our recent article in the Journal [1] provide important suggestions about the experimental design and the role of endothelin in asthma.

Firstly, the levels of immunoreactive endothelin-1 (ET)1 in cell supernatants under basal conditions were somewhat lower in the data of AUBERT et al. [2] than those in ours $[1]\left(<10 \mathrm{pg} \cdot 10^{7}\right.$ cells $^{-1} \cdot 24 \mathrm{~h}^{-1}$ versus $\sim 100 \mathrm{pg} \cdot \mathrm{mL}^{-1} \cdot 24$ $\mathrm{h}$, respectively). Although the reasons why such a discrepancy occurred are unclear, there are several possibilities. Both groups of authors used the same cell line, but the culture conditions, passage conditions and passage number may have influenced the production of the peptide. In cell passage, we used foetal calf serum (FCS) for blocking the trypsin activity used to detach the cells. As J.D. Aubert pointed out, this may be one mechanism. Alternatively, the responsiveness of the cell line may decrease during repeated passages. According to the data 
of AUBERT et al. [2], BEAS-2B cells released only $6.6 \pm 1.9$ $\mathrm{pg} \cdot 10^{7}$ cells $^{-1} \cdot 24 \mathrm{~h}^{-1}$ ET- 1 when stimulated by $10^{-6} \mathrm{M}$ phorbol esters (e.g. phorbol myristate acetate (PMA)), while the same stimulus induced a strong expression of messenger ribonucleic acid (mRNA) by Northern blot analysis. This apparent discrepancy between a little protein production and a strong mRNA expression might have been seen in the aged cells. We have found that after numerous passages the cell line showed decreased responsiveness to proinflammatory stimuli (unpublished observation).

It is also interesting that corticosteroid dexamethasone failed to inhibit ET-1 expression and release in the data of AuBERT et al. [1], whereas our findings showed the suppressing activity of dexamethasone. We agree that the action of dexamethasone may be influenced by exposure to FCS, since the serum consists of a variety of cytokines which can alter the responsiveness of epithelial cells [3]. Another possibility is again the condition of the cells; the decreased responsiveness to the exogenous stimuli might cause an apparent lack of the effect of dexamethasone on ET-1 release. It has been reported that dexamethasone can affect any of the stages of transcriptional rate, degradation of mRNA or protein synthesis [4]. At present, we do not know the exact point of action of this anti-inflammatory agent in our system and further study is needed to address this question. Studies using airway epithelial cells from inflammatory as well as normal states will highlight the functional roles of these cells and their modulation with therapeutic agents.

\section{H. Takizawa}

Dept of Laboratory Medicine, University of Tokyo, School of Medicine, 7-3-1 Hongo, Bunkyo-ku, 113 Japan. Fax: 81 0356890495 .

\section{References}

1. Takizawa H, Desaki M, Ohtoshi T, et al. Erythromycin and clarithromycin attenuate cytokine-induced endothelin-1 expression in human bronchial epithelial cells. Eur Respir J 1998; 12: 57-63.

2. Aubert JD, Juillerat-Jeanneret L, Leuenberger Ph. Expression of endothelin-1 by human bronchoepithelial and monocytic cell lines: effects of tumor necrosis factor- $\alpha$ and dexamethasone. Biochem Pharmacol 1997; 53: $547-$ 552.

3. Beckmann JD, Takizawa H, Romberger D, et al. Serumfree culture of fractionated bovine bronchial epithelial cells. In Vitro Cell Dev Biol 1992; 28A: 39-46.

4. Barnes PJ. Mechanisms of action of glucocorticoids in asthma. Am J Respir Crit Care Med 1996; 154: S21-S27. 